\title{
CONSUMER PREFERENCE ANALYSIS TOWARDS CORN MILK USING KANO MODEL
}

\author{
Ikasari Dhita Morita*, Dewanti Beauty Suestining Dyah, \\ Rohmah Wendra Gandhatyasri, Septifani Riska \\ Agricultural Industrial Technology Department, Faculty of Agricultural Technology, \\ University of Brawijaya, Indonesia \\ *E-mail: dhitamorita@gmail.com
}

\begin{abstract}
The objective of this study is to describe level of acceptance and customer satisfaction towards corn milk produced by ABEC (Agroindustrial Business and Entrepreneurship Center). It utilized the Kano model. The findings showed based on CSC (Customer Satisfaction Coefficient) score that indicated the customer preference, the attributes of the corn milk with the highest CSC was its nutritional value. Its IBT was 0.48 and IWT was -0.58 . The nutritional value contained information related to storage instruction, nutritional content, expiration date, producer contact number, halal label, and production permit (P-IRT). The corn milk packaging should convey those information otherwise customer satisfaction level was getting lower.
\end{abstract}

\section{KEY WORDS}

Customer, preference, satisfaction, corn milk.

Nutrition plays such a pivotal role in human survival. Nutrition can be obtained from daily consumption of food and beverages; one of which is milk. Despite plentiful nutrition it contains, some people cannot digest milk as it may cause intolerance, either lactose intolerance or protein intolerance (Widodo, 2002). In addition, Harianja, et.al (2015) stated that milk from animal is generally more expensive and therefore, some people may not afford it. Therefore, more affordable, accessible and more importantly nutritious type of milk is needed.

Therefore, it takes the raw material of milk maker besides animal milk which is cheap and easy to get but has high nutritional value.

Milk produced from vegetable milk, such as corn milk, can be an alternative to milk from animals more particularly individual with lactose intolerant. As a type of beverage, corn milk is able to provide much needed nutrition because it does not contain any cholesterol (Ikawati, 2013). One of the companies producing corn milk in Malang is ABEC (Agroindustrial Business and Entrepreneurship Center). ABEC is a business unit under the Department of Agricultural Industrial Technology, Faculty of Agricultural Technology, Brawijaya University. $A B E C$ has not conducted any test market yet and as the consequence, the company does not understand whether or not customer are satisfied with their product.

During this time, corn milk produced by ABEC has never been tested consumer acceptance, so the producers have not yet know whether corn milk has met the expectations of consumers or not.

As an innovation, corn milk should be able to meet customer expectation more particularly lactose intolerant individual's need for nutritious milk substitute. Prior to purchase, consumers will make timely and various consideration. Success of a company in introducing product to the market will depend on level of acceptance from customers (Juanda, et.al, 2011). One method that can be used to find out customer perspective towards quality of a product is Kano Method. Kano method is a method that aims to categorize attributes of a product or service based on how well the product or service meeting customer needs or satisfaction (Widiawan, 2004). Advantage of Kano method is that it is able to describe satisfaction and dissatisfaction of consumers towards product attributes simultaneously. However, it has some shortcomings in terms of classification; the method is able to classify every attribute a product has but not a combination of several attributes (Tan, 2004). The 
objective of this study is to obtain information on corn milk customer level of acceptance and customer satisfaction.

\section{METHODS OF RESEARCH}

As many as 100 respondents were involved in the study. Sample size (minimum samples) is determined once the questionnaire had been valid and reliable. Asnawi and Masyhuri (2011) suggested that minimum samples for descriptive study is 100 samples. David Garvin's 8 (eight) dimension of qualities, namely performance, feature, reliability, conformance, durability, serviceability, aesthetic and perception were used to improve the corn milk attributes. Those eight dimensions were then elaborated into several attributes. Table 1 described the questionnaire used to improve customer satisfaction and level of acceptance of the corn milk.

Table 1 - Operational Definition of Corn Milk Attributes

\begin{tabular}{|c|c|c|}
\hline No & Attribute & Operational Definition \\
\hline \multirow[t]{3}{*}{1} & Performance & Flavor \\
\hline & & Price \\
\hline & & Corn aroma \\
\hline \multirow[t]{2}{*}{2} & Feature & No artificial sweetener \\
\hline & & No preservative \\
\hline \multirow[t]{2}{*}{3} & Reliability & Storage information \\
\hline & & Serving instructions \\
\hline \multirow[t]{2}{*}{4} & Conformance & Thickness \\
\hline & & Nutritional Content \\
\hline 5 & Durability & Expired date \\
\hline 6 & Serviceability & Producer or customer service \\
\hline 7 & Aesthetic & $\begin{array}{l}\text { Good packaging } \\
\text { Good design }\end{array}$ \\
\hline \multirow[t]{2}{*}{8} & Perception & Halal brand \\
\hline & & Production permit information (P-IRT) \\
\hline
\end{tabular}

Kano model was used in data analysis method. The data were obtained from the questionnaire. Amran (2010) explained that Kano model was developed based on several analyses, namely:

Designing and trying out questionnaire. The questionnaire aimed at describing customer's opinion towards certain attribute of a product. To describe customer's opinion, questionnaire should be able to reveal two types of information, functional (customer's perception when product has certain attributes) and dysfunctional (customer's perception when product does not have certain attributes). Likert scale, of which score ranges from 1 to 5 , was used for the questionnaire. The scores in the scale conveyed the following information:

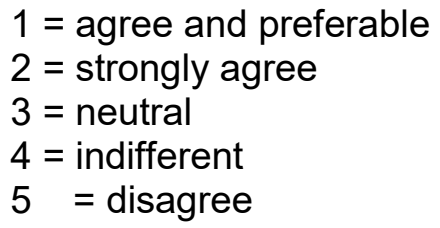

Evaluation and Interpretation. Having distributed the questionnaire to the samples, the data were evaluated in three stages, namely:

Combining the samples' responses on both the functional and dysfunctional questions. The Kano category was used for classifying the responses. The results were several categories describing the product attributes;

Tallying frequency of the Kano categories and then determining the Kano category using Blauth's formula with the following requirements: when frequency of $(O+A+M)$ category $>$ that of $(I+R+Q)$ category, grade obtained was the maximum grade of the $(O, A$, $M)$ category (Ramadhani, 2011); when frequency of $(O+A+M)<$ that of $(I+R+Q)$, grade obtained was the maximum grade of the (I, R, Q) category (Ramadhani, 2011). 
Analyzing the Customer Satisfaction Coefficient (CSC) to describe the customer satisfaction level. The formula for CSC was:

$$
I B T=\frac{A+O}{A+O+M+I} \quad I W T=-\left(\frac{M+O}{A+O+M+I}\right)
$$

Sauerwein as cited in Mufti (2012) stated that IBT referred to "if better than" indicating that average customer satisfaction level would increase if a product had $A$ (attractive) and $O$ (one-dimensional) attributes.

IWT referred to "if worse than" indicating that average customer satisfaction level would increase if a product contained all of the attributes of $\mathrm{M}$ (must be) and $\mathrm{O}$ (one-dimensional).

Once the Kano coefficients for customer satisfaction had been obtained, the scores were transformed into a graph (Amran, 2010). The closer a score was to $(0,1),(-1,1)$ and $(-1,0)$ of the graph, the influence of the attributes was more significant for both customer satisfaction and dissatisfaction (Wijaya, 2009).

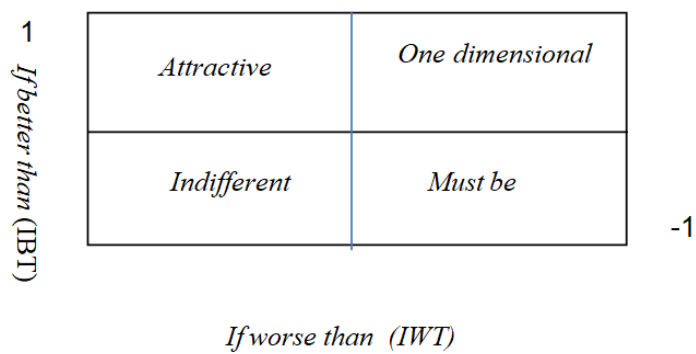

Figure 1 - Kano Coefficient for Customer Satisfaction Graph

The criteria used to decide alternatives in improving product attributes were as follow:

Producers should pay close attention to attributes that customers considered as must be, one dimensional, and attractive;

Taking "indifferent," one of the attributes, into consideration since the attribute does not have any influence towards either customer satisfaction or dissatisfaction;

Avoid "reverse" attribute because it is the attribute customers do not like the most.

\section{RESULTS AND DISCUSSION}

Validity Testing Results. Validity testing was conducted using the product moment correlation formula, making comparison between $r_{\text {ratio }}$ and $r_{\text {table. }}$. When $r_{\text {ratio }}>r_{\text {table, variable }}$ was considered valid.

Table 2 - Validity Testing Result

\begin{tabular}{|c|c|c|c|c|c|}
\hline \multirow{2}{*}{ No } & \multirow{2}{*}{ Product Attribute } & \multicolumn{2}{|c|}{$\mathrm{R}_{\text {ratio }}$} & \multirow[b]{2}{*}{$r_{\text {table }}$} & \multirow{2}{*}{ Description } \\
\hline & & Functional & Dysfunctional & & \\
\hline 1 & Change in flavor & 0.321 & 0.319 & 0.183 & Valid \\
\hline 2 & Change in pricing & 0.233 & 0.218 & 0.183 & Valid \\
\hline 3 & Change in aroma & 0.382 & 0.378 & 0.183 & Valid \\
\hline 4 & Artificial sweetener & 0.146 & 0.222 & 0.183 & F (Not Valid) / D (Valid) \\
\hline 5 & Preservatives & 0.217 & 0.208 & 0.183 & Valid \\
\hline 6 & Serving instruction & 0.505 & 0.627 & 0.183 & Valid \\
\hline 7 & Storage instruction & 0.566 & 0.654 & 0.183 & Valid \\
\hline 8 & Change in thickness & 0.410 & 0.362 & 0.183 & Valid \\
\hline 9 & Nutrient content & 0.665 & 0.677 & 0.183 & Valid \\
\hline 10 & Expiration date & 0.589 & 0.648 & 0.183 & Valid \\
\hline 11 & $\begin{array}{l}\text { Producer's contact number or } \\
\text { customer service information }\end{array}$ & 0.507 & 0.613 & 0.183 & Valid \\
\hline 12 & Change in packaging & 0.530 & 0.496 & 0.183 & Valid \\
\hline 13 & Change in design & 0.609 & 0.578 & 0.183 & Valid \\
\hline 14 & Halal label & 0.571 & 0.600 & 0.183 & Valid \\
\hline 15 & Production permit information (P-IRT) & 0.514 & 0.500 & 0.183 & Valid \\
\hline
\end{tabular}


The SPSS output was used to obtain the $r_{\text {ratio. }}$ Table 2 described the validity testing on the respondents' responses towards the functional and dysfunctional questions.

Based on Table 2, there was one invalid variable, artificial sweetener (attribute 4) categorized as functional attribute. The invalid variable was removed or excluded in the reliability testing.

Reliability Testing Result. The objective of the reliability testing is to describe how consistent an instrument is. In this study, the instrument was reliable if the Alpha Cronbach (a) score $>0.6$. Table 3 described the result of the reliability testing.

Table 3 - Reliability Testing Result

\begin{tabular}{cccc}
\hline Type of Question & Total Item & Alpha Cronbach $(\alpha)$ & Description \\
\hline Functional & 15 & 0.725 & Reliable \\
Dysfunctional & 15 & 0.753 & Reliable \\
\hline
\end{tabular}

Customer's Preference using Kano Model. Based on the customer's preference, the categories for each of the product attribute were must be, attractive, one dimensional, reverse and indifferent. The categories were selected based on the Blauth's Formula or the highest of must be, one dimensional, attractive, indifferent, reverse and questionable. The attributes classified as one dimensional should be prioritized since customer satisfaction level is strongly related to performance of the attributes (Nofirza and Indrayani, 2011). The attributes categorized as one dimensional were storage information, nutritional content, producer's or customer service contact information, halal label and production permit information (P-IRT). The highest percentage was the production permit information (P-IRT) of which percentage was $39.13 \%$.

The attributes categorized as attractiveness should be maintained as the level of customer satisfaction will increase as these attributes were getting higher and at the opposite, the customer satisfaction would decline if these attributes were getting lower (Nofirza and Indrayani, 2011). The attributes categorized as attractiveness were serving instruction and the percentage was $18.27 \%$. At the same, they were also categorized as must-be. Must-be referred to attributes customers find necessary and their satisfaction would decrease as their performance was getting lower. Customers consider attributes that fall within this category as a necessity in a product. However, at the same time, customer satisfaction will not increase far above neutral even though the performance of these attributes is high. Must-be was a weak statement of satisfaction but more positive than neutral (Nofirza and Indrayani, 2011). The attributes classified as the must-be category were serving instruction and expiration date. The expiration date had the highest percentage that was $40.87 \%$.

The customers did not pay close attention towards the indifferent category since it does not influence increase or decrease in the customer satisfaction (Nofirza and Indrayani, 2011). The attributes categorized as indifferent were change in flavor, price, and aroma as well as artificial sweetener, change in thickness, packaging and design of the packaging. Change in packaging had the highest percentage that was $62.6 \%$.

Attributes categorized as reverse should be eliminated as they would decrease customer satisfaction. The attribute fell into the category was artificial sweetener. The percentage of the attribute was $62.61 \%$.

Customer Satisfaction Coefficient in the Kano Customer Satisfaction Coefficient Graph. CSC (Customer Satisfaction Coefficient) showed both satisfaction and dissatisfaction coefficient; the coefficient represented customer preference towards certain product. IBT score represented how much attribute of a product influence customer satisfaction. The closer IBT score is to 1 , the more significant influence an attribute has towards customer satisfaction. IWT score means there is not any product attribute that has influence towards customer satisfaction. The closer IWT score to -1 , the more significant influence an attribute has towards customer satisfaction. Table 5 described the IBT and IWT scores of the product attributes. 
Table 4 - Kano Category Frequency and Kano Category Results of the Corn Milk Attributes

\begin{tabular}{|c|c|c|c|c|c|c|c|c|c|c|c|}
\hline No & Product Attributes & $\mathrm{A}$ & $\mathrm{O}$ & $\mathrm{M}$ & 1 & $\mathrm{R}$ & Q & $A+O+M$ & $1+R+Q$ & Total & Category \\
\hline 1 & Change in flavor & $16.50 \%$ & $6.09 \%$ & $1.74 \%$ & $49.50 \%$ & $23.48 \%$ & $2.69 \%$ & $24.33 \%$ & $75.67 \%$ & 100 & 1 \\
\hline 2 & Change in pricing & $6,95 \%$ & $4.35 \%$ & $10.43 \%$ & $58.27 \%$ & $16.52 \%$ & $3.48 \%$ & $21.73 \%$ & $78.27 \%$ & 100 & $\mathrm{I}$ \\
\hline 3 & Change in aroma & $7,83 \%$ & $3.48 \%$ & $5.22 \%$ & $50.43 \%$ & $33.04 \%$ & 0 & $16.53 \%$ & $83.47 \%$ & 100 & 1 \\
\hline 4 & Artificial sweetener & $3,48 \%$ & $0.87 \%$ & $0.87 \%$ & $31.30 \%$ & $62.61 \%$ & $0.87 \%$ & $5.22 \%$ & $94.78 \%$ & 100 & $\mathrm{R}$ \\
\hline 5 & Preservatives & $6,09 \%$ & $1.74 \%$ & $0.87 \%$ & $46.08 \%$ & $43.48 \%$ & $1.74 \%$ & $8.70 \%$ & $91.30 \%$ & 100 & I \\
\hline 6 & Serving instruction & $18.27 \%$ & $17.39 \%$ & $18.27 \%$ & $42.6 \%$ & $2.6 \%$ & $0.87 \%$ & $53.93 \%$ & $46.07 \%$ & 100 & $A \& M$ \\
\hline 7 & Storage instruction & $13.91 \%$ & $26.10 \%$ & $22.61 \%$ & $33.04 \%$ & $4.34 \%$ & 0 & $62.62 \%$ & $37.38 \%$ & 100 & 0 \\
\hline 8 & Change in thickness & $11.3 \%$ & $7.83 \%$ & $5.22 \%$ & $53.91 \%$ & $20 \%$ & $1.74 \%$ & $24.35 \%$ & $75.65 \%$ & 100 & I \\
\hline 9 & Nutrient content & $13.91 \%$ & $32.17 \%$ & $23.47 \%$ & $26.1 \%$ & $3.48 \%$ & $0.87 \%$ & $69.55 \%$ & $30.45 \%$ & 100 & $\mathrm{O}$ \\
\hline 10 & Expiration date & $2.61 \%$ & $38.26 \%$ & $40.87 \%$ & $11.3 \%$ & $5.22 \%$ & $1.74 \%$ & $81.74 \%$ & $18.26 \%$ & 100 & $\mathrm{M}$ \\
\hline 11 & $\begin{array}{l}\text { Producer's contact number or } \\
\text { customer service information }\end{array}$ & $12.17 \%$ & $26.96 \%$ & $23.48 \%$ & $31.3 \%$ & $2.61 \%$ & $3.48 \%$ & $62.61 \%$ & $37.39 \%$ & 100 & $\mathrm{O}$ \\
\hline 12 & Change in packaging & $18.27 \%$ & $7.83 \%$ & $6.95 \%$ & $62.6 \%$ & $3.48 \%$ & $0.87 \%$ & $33.05 \%$ & $66.95 \%$ & 100 & $\mathrm{I}$ \\
\hline 13 & Change in design & $26.10 \%$ & $13.04 \%$ & $9.56 \%$ & $49.56 \%$ & $0.87 \%$ & $0.87 \%$ & $48.70 \%$ & $51.30 \%$ & 100 & I \\
\hline 14 & Halal label & $12.17 \%$ & $33.91 \%$ & $26.10 \%$ & $25.21 \%$ & $2.61 \%$ & 0 & $72.18 \%$ & $27.82 \%$ & 100 & $\mathrm{O}$ \\
\hline 15 & $\begin{array}{l}\text { Production permit information } \\
\text { (P-IRT) }\end{array}$ & $6.09 \%$ & $39.13 \%$ & $30.43 \%$ & $21.74 \%$ & $1.74 \%$ & $0.87 \%$ & $75.65 \%$ & $24.35 \%$ & 100 & $\mathrm{O}$ \\
\hline
\end{tabular}

Table 5 - CSC Scores of the Corn Milk Attributes

\begin{tabular}{|c|l|c|c|c|c|c|}
\hline No & Product Attribute & $\mathrm{A}+\mathrm{O}$ & $\mathrm{M}+\mathrm{O}$ & $\mathrm{A}+\mathrm{O}+\mathrm{M}+\mathrm{I}$ & $\mathrm{IBT}$ & $\mathrm{IWT}$ \\
\hline 1 & Change in flavor & 26 & 9 & 79 & 0.33 & -0.11 \\
\hline 2 & Change in pricing & 13 & 17 & 92 & 0.14 & -0.18 \\
\hline 3 & Change in aroma & 13 & 10 & 77 & 0.16 & -0.13 \\
\hline 4 & Artificial sweetener & 5 & 2 & 42 & 0.12 & -0.04 \\
\hline 5 & Preservatives & 9 & 3 & 63 & 0.14 & -0.04 \\
\hline 6 & Serving instruction & 41 & 41 & 111 & 0.37 & -0.37 \\
\hline 7 & Storage instruction & 46 & 56 & 110 & 0.41 & -0.51 \\
\hline 8 & Change in thickness & 22 & 15 & 90 & 0.24 & -0.17 \\
\hline 9 & Nutrient content & 53 & 64 & 110 & 0.48 & -0.58 \\
\hline 10 & Expiration date & 47 & 91 & 107 & 0.44 & -0.85 \\
\hline 11 & Producer's contact number or customer service information & 45 & 58 & 108 & 0.41 & -0.53 \\
\hline 12 & Change in packaging & 30 & 17 & 110 & 0.27 & -0.15 \\
\hline 13 & Change in design & 45 & 26 & 113 & 0.4 & -0.23 \\
\hline 14 & Halal label & 53 & 69 & 112 & 0.47 & -0.61 \\
\hline 15 & Production permit information (P-IRT) & 52 & 80 & 112 & 0.46 & -0.71 \\
\hline
\end{tabular}

Based on the IBT scores, the nutritional value had the highest IBT score that was 0.48 . Halal label had the second highest attribute or 0.47 . Production permit information (P-IRT) had the third highest IBT score or 0.46 . The IBT scores of the product attribute revealed the following information:

1 Nutritional content would increase the customer service by $48 \%$;

2 Halal label would increase the customer service by $47 \%$;

3 Production permit information (P-IRT) would increase the customer service by $46 \%$;

4 Expiration date would increase the customer service by $44 \%$;

5 Storage information and producer or customer service contacts would increase the customer service by $41 \%$.

Based on IWT scores, the expiration date had the highest IWT score or -0.85 . Production permit information (P-IRT) was the attribute with the second highest IWT score or -0.71 . Halal label was the attribute with the third highest IWT score or -0.61 . The IWT scores of the product attribute revealed the following information:

1 Expiration date would increase the customer service by $85 \%$;

2 Production permit information (P-IRT) would increase the customer service by $71 \%$;

3 Halal label would increase the customer service by $61 \%$;

4 Nutritional content would increase the customer service by $58 \%$;

5 Producer or customer service information would increase the customer service by $53 \%$;

6 Storage information would increase the customer service by $51 \%$.

The Kano customer satisfaction coefficient (IBT and IWT) of each of the product attributes was later transformed into a graph. Figure 1 described graph describing Kano customer satisfaction coefficient. The graph provided information revealing position of an attribute towards the Kano category and how much influence it had towards the customer satisfaction or dissatisfaction. 


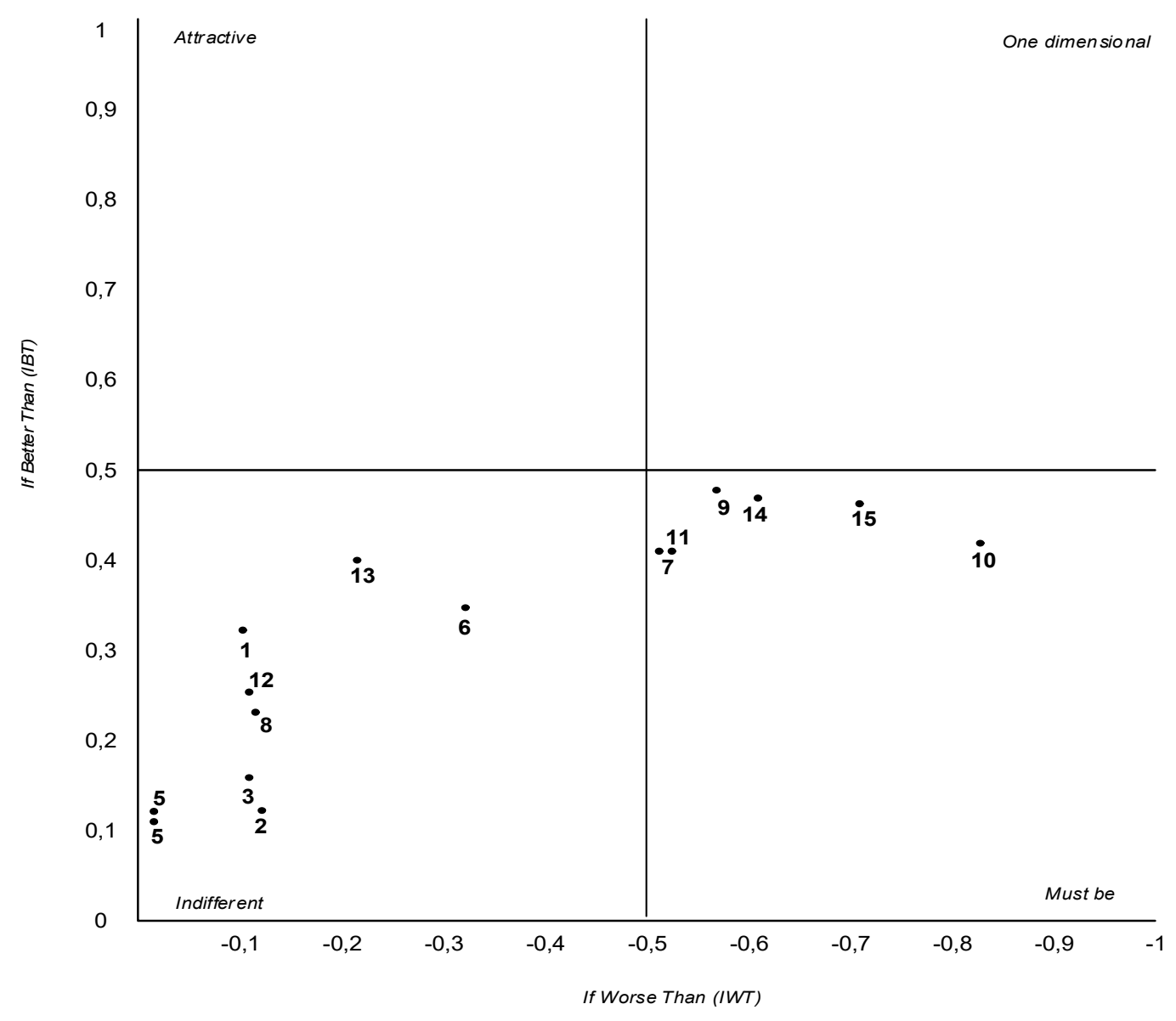

Figure 2 - Kano Customer Satisfaction Coefficient Graph

Based on Figure 2, the attributes categorized as must-be were storage instruction (attribute 7), nutritional content (attribute 9), expiration date (attribute 10), producer or customer service contacts (attribute 11), halal label (attribute 14), and production permit information (attribute 15). Product should provide all of these attributes because they influenced customer satisfaction; when these attributes had high performance, customer satisfaction increased and vice-versa. The attributes considered as indifferent were change in flavor (attribute 1), change in price (attribute 2), change in aroma (attribute 3), artificial sweetener (attribute 4), preservatives (attribute 5), serving instruction (attribute 6), thickness (attribute 8), change in packaging (attribute 12), and change in packaging (attribute 13). These attributes did not have any influence towards an increase or decrease in customer satisfaction.

\section{CONCLUSION}

Based on the findings and discussions, the conclusions are:

Based on the IBT score, the attribute that has really significant influence towards the customer satisfaction is nutritional value of which percentage is $48 \%$;

Based on the IWT score, the attribute that has really significant influence towards the customer satisfaction is expiration date of which percentage is $85 \%$;

Based on the Kano coefficient graph mapping, the attributes categorized as must-be are the storage instruction, nutritional content, expiration date, producer or customer service contacts, halal label, and production permit information. Product should provide all of these attributes because they influence customer satisfaction; when these attributes have high performance, customer satisfaction increases and at the opposite when they have poor performance, the customer satisfaction will decrease. 


\section{REFERENCES}

1 Amran, T. G and Ekadeputra. 2010. Pengukuran Kepuasan Pelanggan Menggunakan Metode Kano dan Root Cause Analysis (Studi Kasus PLN Tangerang). Jurnal Jurusan Teknik Industri. FTI. Trisakti University. Jakarta.

2 Asnawi \& Masyhuri. 2011. Metodologi Riset Manajemen Pemasaran. Malang: UIN Maliki Press

3 Harianja, C. H., Rusmarilin, H., and Yusraini, E. 2015. Pembuatan Susu Jagung dengan Pengayaan Kacang Hijau Bergerminasi dan Penambahan Cmc Sebagai Penstabil. Jurnal Rekayasa Pangan dan Pertanian 3(1).

4 Ikawati, M. N. 2013. Pemanfaatan Sukun (Arthocarpus Altilis) dan Susu Jagung (Zea Mays) dalam Pembuatan Es Krim dengan Penambahan CMC (Carboxy Methyl Cellulose). Published Manuscript. Department of Biology Education, Faculty of Education and Teacher Training. Muhammadiyah University of Surakarta. Surakarta.

5 Juanda, J., Cut E., and Hanum V.M. 2011. Studi Preferensi Konsumen Terhadap Roti Tawar Labu Kuning (Cucurbitamoschata). Jurusan Teknologi Hasil Pertanian. Faculty of Agriculture. Syiah Kuala Darussalam University. Banda Aceh.

6 Nofirza, I. K. 2011. Aplikasi Metode Kano Dalam Analisis Indikator Kualitas Pelayanan di Rumah Sakit Arifin Ahmad Pekanbaru. Jurnal Sains, Teknologi dan Industri. 9(1): 1-8.

7 Tan, K. C. 2004. Optimizing Product Design Using Teh Kano Model and QFD. IEE. International Engineering Management Conference, 8e21 Oct., pp1085e1089.

8 Widodo, W. 2002. Bioteknologi Fermentasi Susu. Center for Biotechnology Development, Muhammadiyah University of Malang. Malang.

9 Wijaya, T. 2011. Manajemen Kualitas Jasa. PT. Index. Yogyakarta. 